\section{STUDY OF THE BRITISH FLORA}

T his presidential address to Section K, Prof. J. R. Matthews begins by referring to some of the more noteworthy landmarks in the history of British botany. The exact recording of native plants, an essential preliminary to the formulation of any scientific account of them, dates from the time of William Turner. Although new records have continued to be made down to the present time, the discovery and discrimination of more than a thousand species of vascular plants before the death of John Ray in 1705 remains an outstanding tribute to the work of the early explorers. Much of the subsequent floristic work was carried out by botanists who made no claim to be called professional, and it often found expression in the publication of local or county floras. The value of these surveys could not be seriously doubted, and there is a growing need for their encouragement and support by all responsible authorities, public or private, who have the desire to see a revival of interest in the scientific study of local natural history.

The edifice of British botany raised by the early naturalists gradually became expanded and enlarged, and by the end of the nineteenth century, knowledge of the composition of the native flora was relatively complete. The distribution of plants had also attracted considerable attention, and Great Britain had become one of the best botanically explored countries in the world. But along with other subjects, botany shared in the general scientific renaissance which occurred in the early years of the twentieth century. Although the systematic study and recording of plants continued, greater emphasis began to be laid on the ecological approach to field studies. The investigation of heredity and the study of variation by the experimental method and the advance of cytology were at once recognized as sources of valuable data contributing towards an understanding of the species problem, which had followed the enunciation of the Darwinian theory of evolution. Detailed ecological studies of individual species throughout the range of distribution were necessary, if the responses to changing environmental conditions were to be correctly interpreted. Such investigations were closely connected with problems of taxonomy, since it was evident that much intraspecific variation was related to envirommental gradients. It should therefore become the purpose of experimental taxonomy to examine and analyse the heterogeneous nature of the species complex and correlate the results of such analysis with those derived from physiological and ecological studies. Investigations along these lines would prove of immense value in the application of scientific botany to the practice of horticulture, agriculture and forestry.

\section{THE SCHOOL IN A PROGRESSIVE SOCIETY}

T his presidential address to Section L (Education), 1 Mr. W. O. Lester Smith points out that school business has increased rapidly in recent years, affecting each of the leading partners in educational administration-the Ministry of Education, the local authority, the head teacher and his colleagues. It is worth considering how this has come about, and there would seem to be three main causes: social change, the widening scope of education, and the modern emphasis on management. The administrative pressure on the head teacher is more serious in its consequences than that on the other two partners, because hitherto in Great Britain we have regarded the school as the natural growing point of educational thought and technique, and we owe much to the creative wisdom of some of our great head teachers.

It is usual to attribute the increase of administration to the growing demands of Government depart. ments; but this is a partial diagnosis, for the preoccupation of the head teacher with managerial detail began not in the schools associated with the State but in the independent public schools from the days of Thring onwards. It was due largely to the emphasis in these schools on an active corporate life and on giving each pupil a full or 'total' education. In a sense, therefore, the criticized Rugby appointment of an administrator as head master was but a logical recognition of a process that has been unfolding itself for a century.

The head teachers of the primary and secondary schools associated with the State in Britain are now being diverted from their educational task by a growing administrative pressure, and this is particularly unfortunate because the abolition of the elementary school by the Butler Act was a historic opportunity, and the heads of the schools emerging from the elementary tradition ought to be free to concentrate on the difficult task of making education a living force in the social democracy now taking shape. Just when imaginative leadership is urgently necessary, the head teacher's function is becoming increasingly managerial as a result of the growth of corporate activities, the demands of society, and the aftermath of Govermment schemes and schemes launched by well-meaning importunate organisations.

Some of the new demands are necessary and desirable, but others are hard to justify. There is also an increasing use of schools for extraneous purposes, involving the necessity of putting away daily all equipment and appurtenances of educational or resthetic value. We cannot hope to achieve quality unless we are prepared to put education first; and it is regrettable that, owing to shortages of staff and buildings, we make a habit of measuring progress in quantitative terms. The schools of the people were for centuries retarded by what Defoe called the law of subordination, and to-day Demos is apt to treat his schools like the old feudalism writ large.

One of the most difficult issues is to determine the extent to which schools should respond to the many claims which society makes upon them. There is general agreement that they cannot to-day thrive in isolation, or, as the McNair Report puts it, teachers cannot be "a race apart". On the other hand, there is a limit to sociability, a plimsoll line at which service to the community becomes a danger to education. If a service rendered by a school fits naturally into the curriculum or the corporate life, it may provide useful educative experience; but if there is a marriage of convenience designed primarily to further an extraneous scheme, there can be serious waste of teacher-and pupil-time without compensating advantage. We ought, as a nation, to recognize before it is too late that the essential function of each school is to educate, and that of each head teacher to give expert guidance to his team in the conduct of an extremely difficult operation, requiring human sympathy and a sure grasp of the intricate problems of childhood and adolescence. 